\title{
The Impact of COVID-19 Pandemic Outbreak: Experiences of Sri Lanka
}

\author{
Professor Thanabalasingam Krishnamohan *, Mr.Kandasamy Sathiyasegar ** \\ * Professor in Political Science, Department of Social Sciences, Eastern University, Sri Lanka, Chenkalady, Sri Lanka \\ ${ }^{* *}$ Senior Lecturer in Sociology \& Anthropology, Department of Social Sciences, Eastern University, Sri Lanka, Chenkalady, Sri Lanka \\ DOI: 10.29322/IJSRP.11.04.2021.p11262 \\ http://dx.doi.org/10.29322/IJSRP.11.04.2021.p11262
}

\begin{abstract}
The first confirmed victim of COVID-19 in Sri Lanka was identified in the latter part of January 2020. There was no vaccine in the world for COVID-19 at that time, the Government of Sri Lanka encouraged the people to strictly adhere to the social distancing to prevent the decline of the public health sector like other countries, for the prevention of the second wave, and to control the spread of the disease. Similar to all other countries, the Government of Sri Lanka either abandoned or postponed all important events, ordered all educational activities including schools and universities to be closed and controlled the operation of workplaces in the state and private sectors, and implemented work from home. From mid-March to June 2020 strict lockdown operations were carried out in Sri Lanka. On March 20, 2020, a nationwide police curfew was imposed without an emergency order, and inter-district travel was also soundly restricted. The main purpose of the police curfew order was to enforce locking across the country and reduce contact with infected individuals, thereby reducing the rate of transmission of the pandemic disease. A curfew order was the only legal choice for a newly elected president because the parliament had been dissolved at that time and general elections were pending, and the country was governed without a parliament. Three populated districts, namely Colombo, Kalutara, and Gampaha, had been identified as high-risk areas for the pandemic. All public gatherings and meetings, festivals, and celebrations were prohibited under the order of the police curfew. But the government gradually approved the opening of salons, beauty salons, and barber shops, but strictly prohibited shaving. The government urged barbers to follow precautionary hygienic measures when having a haircut. Thus, this research paper attempts to achieve the following key objectives: (i) implications of the COVID-19 pandemic in Sri Lanka from March 2020 until to date (ii) the impact of the COVID-19 epidemic on the general election held in the country (iii) impacts on the health and SocioEconomic factors (iv) effectiveness of the early warning management system to control the pandemic environments.
\end{abstract}

Index Terms- Leadership, Online system, Elections, Lockdown, Outbreaks

\section{INTRODUCTION}

$\mathrm{T}$ The COVID - 19 pandemic virus was identified in Wuhan city in China in December 2019. From that time onwards, it has been spreading not only in China but worldwide. Consequentially, it created many disputes, impacts, and challenges in the routine life of the people and impacted in the socio, economic, education, political, environmental, and cultural aspects. Social scientists have to share lessons learned at the national level as well as the global level from past epidemics. Researchers have to build a clear vision regarding the influences of the pandemic on different communities with various social and cultural structures in various local contexts. The social science documentation and evidence may provide tangible ways to better address the social, political, and economic dynamics of the epidemic. In this regard, the evidence promotes global interventions that build on the social and cultural resources of the communities. The Covid-19 pandemic outbreak created many health problems, and it caused a handful of socio-economic and political crises, it means a direct impact on the socio-economic and politics in Sri Lanka. In this way, the article is focusing on the aspects of health and socio-economic and political impacts, and disaster management, advocacy, and monitoring with an early warning system of the pandemic situation in Sri Lanka. Further, it presents a brief overview of socio-economic and political life in Sri Lanka and examines reactions to what Sri Lanka implements and a range of more effective alternative approaches. Even though the research problems cover a broad area, the research is mainly focusing on the Sri Lankan context. This is socio-economic-political research, and it is developed using the descriptive research method, and the related variables are analyzed and measured mainly focused on the qualitative approach methodology. The appropriate approaches have been used for this research and simple random sampling techniques are used for the data collection process. The primary data were collected using an observational method, and case studies for this study. Also, it is incorporating data collected from research Journals, Articles, and various facts collected from both the printed and electronic versions which are available in Social and Mass Media.

\section{Prevention Mechanisms}

A curfew (police curfew) was imposed across the island to control the spread of the virus. A few weeks later, a curfew was imposed across the country only at night. However, curfew was imposed in Colombo, Kalutara, and Gampaha districts of the Western Province for three consecutive months. The curfew order was lifted nationwide on June $28^{\text {th }}, 2020$ with pandemic issues. After a few months of effectively controlling the first wave of viral infection, in early October, the second wave of COVID-19 spread 
rapidly from both the garment factory and the fish market in Colombo have been identified as new outbreaks.

A state of emergency must first be declared to facilitate a curfew order to be declared. Only then can a curfew order be issued. Parliament should have convened to declare a state of emergency, but the COVID-19 pandemic outbreak occurred during the dissolution of parliament for the general election, so that the president could not declare a state of emergency through the parliament. Opposition parties continued to demand the reconvening of the dissolved parliament using Article 70, para (3), sub-para (i) of the Constitution, (The Constitution of Democratic Socialist Republic of Sri Lanka (As Amended Up to $29^{\text {th }}$ October 2020) Revised Edition - 2021) which states that the dissolved parliament must be reconvened in an emergency. Ignoring this, the President issued a police curfew on March 20 ${ }^{\text {th }}$, 2020 (Garda World, 20 Mar 2020, 11:49 AM UTC). Political activists, social activists, and the opposition criticized it as a violation of fundamental rights. They also accused the president of wielding more power than the constitution provides. However, the curfew imposed during the first wave was not enforced in Sri Lanka during the second wave. However, inter-district traffic was banned for some time. Non-essential transportation between inter-districts is prohibited. All passenger transportation, including train service, was also banned. A curfew and a lockdown system have been put in place to facilitate this and help in maintaining the social distance.

In this way, the Government of Sri Lanka has adopted the following procedures to control the spread of COVID-19 viruses. They are.

a) A curfew (police curfew) has been issued across the island,

b) Public gatherings are prohibited,

c) Religious places of worship are closed,

d) All educational institutions such as schools, colleges, universities were closed,

e) Non-essential services are also prohibited,

f) Work from home (online mode) system has been implemented across the country.

The government has been introducing a 14 days quarantine system from the day Sri Lanka first identified the COVID-19 patient, for which forty-one (41) quarantine centers have been set up across the country under the monitoring of the Sri Lankan Forces and Police. Sri Lankan residents, as well as those who exit Sri Lanka for a maximum of seven days for official or business purposes, may also obtain prior permission to quarantine at home for seven days upon return, instead of 14 days at a special facility (Garda World,19 Mar 2021, 05:12 AM UTC).

The Army, Police, and Intelligence service coordinated the activities with the Ministry of Defense. It also played a key role in reducing the spread of the disease to the state intelligence service. With the help of the Public Health Department, the investigation team, along with the police and the army, isolated foreigners entering Sri Lanka for 14 days in isolation centers or self-isolation centers.

This publication is licensed under Creative Commons Attribution CC BY

http://dx.doi.org/10.29322/IJSRP.11.04.2021.p11262
Co-Chair at the National Strategic Enforcement level facing the infection of the Commander-in-Chief of the Sri Lanka Army and Army Commander. Various security agencies such as the military and police (which are also under the Ministry of Defense and Public Security) took swift preventive measures. Sri Lankan military intelligence played a key role in gathering information and acting against the victims and those associated with them. The army, in coordination with police and health officials, sought to isolate the suspected cases.

The Sri Lankan government has suspended entry visas to Bahrain, Canada, Denmark, France, Germany, Italy, the Netherlands, Iran, Qatar, South Korea, Spain, and Sweden. Individuals from abroad and all people suspected of having contact with them were taken to these quarantine centers. They were asked to self-isolate in their homes under strict regulations (Garda World,20 Mar 2020|11:49 AM UTC). During the period of isolation, the army provided food and all necessary facilities to the people. And anyone identified as COVID-19 positive was immediately referred to hospitals dedicated to COVID-19 treatment in the country. Also, the military assisted the police and other law enforcement agencies in maintaining locking operations across the country. Everyone worked together to identify foreigners from abroad, infected areas were identified and isolated from other areas, and police protected the infected areas.

Sri Lanka is one of the few developing countries in the world to have a well-developed public health sector. After identifying some Sri Lankans with the virus in early March, medical experts urged the government to immediately implement locking measures. The Government Medical Officers 'Association (GMOA), the country's leading medical practitioners' union, has issued a letter to the President asking him to close all ports (airports and ports) entering the country. Also, the GMOA recommended extending the local holiday New Year, which is already in effect, to prevent unnecessary travel and crowding (News $1^{\text {st }}, 16$ Mar 2020, 3:43 PM). The GMOA called on the government to seek Chinese-style lockdowns in some parts of Sri Lanka to prevent the spread of COVID-19. The Ministry of Health and its medical experts have been conducting media campaigns to educate the public on the nature of COVID-19 and how to take preventive measures to prevent the spread of the virus.

Department of Medicine and Public Health on 9th April 2020, the Ministry of Health and Indigenous Medical Services released a plan to prevent the spread of COVID-19. The project was designed following the World Health Organization's guidelines. It was designed to prevent the spread of the coronavirus in the community or clusters. It included the following items in the plan controlling the spread of the virus from humanto-human Identity, maintain and cure the patient communicate quickly with the community at risk, and take action against misinformation

\section{IMPRESSIVE POLITICAL LEADERSHIP AND ELECTIONS}

For the first time in the history of Sri Lanka, COVID-19 created the conditions for governing without a parliament. This led to a slightly constitutional crisis. Gotabhaya Rajapaksa contested 
the presidential election on behalf of the Sri Lanka Podujana Peramuna (SLPP) and won in November 2019. Following this, the incumbent government handed over its power to the SLPP and took over the opposition seat. The SLPP, however, was forced to rule without a majority in parliament. After taking office, the SLPP government failed to vote on the report of account submitted to parliament (Krishnamohan.T, 2020). As a result, President Gotabhaya Rajapaksa dissolved parliament on March 2, 2020, after four years and six months according to the Nineteenth Amendment. He also announced in the Gazette that April $25^{\text {th }}$, 2020, was the date for the general election.

The Constitution of Sri Lanka provides the President with the power to dissolve Parliament four and a half (4-1 / 2) years after the commencement of the term of office of a parliament. In other words, early as six months before the completion of the full five-year term, the President can dissolve the Parliament (Krishnamohan.T and Sathiyasegar. K, 2020). This power to dissolve parliament is vested to the President by Article 70 (10) and section (2) (e) of the constitution. Following these provisions, and per the provisions of section 10 of the parliamentary elections Act No. 1 of 1981, the President of Sri Lanka, Gotabhaya Rajapaksa, dissolved the parliament at midnight on March $2^{\text {nd }}$, 2020, and announced the election for a new parliament would be held on April $25^{\text {th }}$. He also called on the new parliament to begin its session on May $14^{\text {th }}, 2020$ (The Gazette of the Democratic Socialist Republic of Sri Lanka, Extraordinary, and No. 2165 /8 Monday, March 02, 2020).

Subsequently, a nationwide curfew was imposed, and a lockdown was imposed starting March 20, 2020, as the first wave of COVID-19 outbreaks increased. The country was forced to remain in lockdown until the 28th of April. However, the COVID19 pandemic threatened the parliament election arrangement. Sri Lanka reported its first COVID-19 pandemic case of the disease on 10th March. Though the arrangement for the elections was going on, on $17^{\text {th }}$ March, Sri Lanka entered a nationwide lockdown to curb the spread of the virus.

On $19^{\text {th }}$ March, the Chairman of the Election Commission of Sri Lanka declared that the elections could not be held on $25^{\text {th }}$ April as scheduled, referring to instructions from the Government Medical Officers' Association (GMOA) that the country's health and medical conditions were in jeopardy. A new election date would be announced once the situation was under control, he declared. Only COVID-19 itself can decide when the elections can be held, he further declared. The postponement was declared officially in a gazette notification which was published on $21^{\text {st }}$ March.

Despite the COVID-19 pandemic in Sri Lanka, the government was stubborn that elections should be held on April $25^{\text {th }}$ as planned (Krishnamohan.T and Sathiyasegar. K, 2020). The Election Commission banned political parties from holding election rallies, mass meetings, and campaigns against the government.

The Election Commission of Sri Lanka had two challenges regarding the 2020 parliamentary elections. One was whether elections could be held within the period defined by the Constitution. The second was whether the election date should be reconsidered due to the COVID-19 epidemic that had already begun to affect the country. Eventually, the parliamentary election had to be postponed twice.

The President's office was not interested in seeking advice from the Supreme Court on conducting parliamentary elections. On April $9^{\text {th }}$, the secretary to the president responded in writing that it was the duty of the Election Commission to abandon its warning of a constitutional crisis and hold parliamentary elections. Finally, the parliamentary elections were not held on April $25^{\text {th }}$ amid the spreading COVID-19 pandemic. And the Election Commission prepared to postpone the general election until June $20^{\text {th }}$.

As a challenge to the Gazette notification, the newspaper editor Victor Ivan and seven others on $5^{\text {th }}$ May 2020, Samagi Jana Balawegaya and Champika Ranawaka of Jathika Hela Urumaya on $6^{\text {th }}$ May 2020, Kumara Welgama of New Sri Lanka Freedom Party on $9^{\text {th }}$ May, filed a fundamental right before the Supreme Court (Colombo Page News Desk, Jun 2, 2020).

The petition stated, holding parliamentary elections on June $20^{\text {th }}$ is against the provisions of the constitution. The petitioners also contended that the President's gazette notification on dissolving the parliament was invalid as the new parliament could not be convened within three months of its dissolution. Moreover, the petitioners observed that free and fair elections were unable to be held in the context of the COVID -19 crisis as the pandemic has not yet been brought under control. The healthrelated risk would seriously hamper the campaign efforts and they needed free and fair elections. The petitioners, therefore, asked the Supreme Court to give a verdict that the fundamental rights of the people are being violated by holding elections before the conclusion of the COVID -19-virus pandemic.

A five-member panel of the Supreme Court judges began the hearings on May $18^{\text {th }}$ to determine whether all the seven petitions filed against the general election scheduled for June 20th should be taken up for the hearing or not. After a ten-days hearing, the five Supreme Court judges unanimously dismissed the case, saying the petitions would not be heard. Following this, the Election Commission announced August 5th, 2020, as the new date for holding parliamentary elections (Colombo Page News Desk, Jun 2, 2020). Considering public health, the Ministry of Health, and Indigenous Medical Services, in conjunction with the Election Commission, issued "Health Guidelines for Conducting Elections during the COVID-19 Period" on June 3rd, 2020. Comprehensive special health measures indicated in place to protect the public, election officers, and other persons involved in the election from COVID-19 in the Guidelines.

These guidelines provided the following measures to be observed at all stages of the elections, including the campaign period, voting, counting, and post-election activities: wearing a face mask, keeping a social distance of one meter between everyone, washing hands with soap and water or alcohol-based sanitizer as frequently as possible, covering coughs and sneezes 
with elbows or tissues, refraining from touching faces, noses, and eyes.

The Election Commission of Sri Lanka conducted a series of mock polls to test the health guidelines for the election. Several election observation groups participated and provided inputs on the conduct of the mock polls (The New Indian Express, $14^{\text {th }}$ June 2020 04:51 PM). The mock polls permitted the Election Commission to identify the best approaches for the implementation of the health guidelines and observe the preparedness of voters during the pandemic.

The parliamentary elections on August $5^{\text {th, }} 2020$ were the first election in the last two decades to be held without any international observers. The global threat of the COVID-19 epidemic has put great stress on election observers, human rights defenders, and democrats. Although severe conditions were caused by infection, people must be vigilant to ensure that fundamental rights are guaranteed and that democracy prevails.

\section{EDUCATION}

The COVID-19 epidemic situation has created many educational practical problems in the academic life of students and teachers, and this has led to many cultural consequences in the life of students and teachers. Healthcare workers provided advice and guidance to people on how to follow hygienic practices such as maintaining social distance, wearing face masks, and washing their hands frequently. All educational institutions faced many challenges due to the above instructions and all educational institutions including pre-schools, primary, secondary, and tertiary institutions were closed non-announced a reopening date. Instead, the Sri Lankan government introduced online learning and teaching methods. The newly introduced online learning and teaching activities could be a relief to alleviate the long delays seen in educational activities. Thus, online education activities help students to continue their education to this day, but on the other hand, it creates inequalities in matters such as equality expected in the education system. The online teaching and learning process is a new system not only for teachers and students but also for parents and the entire community. The country has not been prepared enough to use the virtual mode education system introduced without any pre-arrangement. That is, the country is not self-sufficient in infrastructure for online education. Without basic electronic tools for online education such as smartphones, laptops, and computers, village-level students faced many challenges.

Expecting students in a largely rural environment to access e-learning and pursue education was a mockery of their poverty. The newly introduced online education system for school students has become one of the most difficult challenges, especially for students pursuing primary education. These students were unable to engage themselves in participation and involvement as they joined the online classroom. So, the parents were under pressure to help their children with their online education activities. Parents, especially those living in rural areas of the country, did not have enough technical knowledge and skills to help their children with this new online system of education.
The towers were also a precursor to the governmentsponsored communications to all the villages. Although contact towers were set up in many villages, Coverage was difficult to access. The students also had to wander with their textbooks in search of places where Coverage was available. Some students also shared their experiences of climbing elevated places for online classes. This is evidence that there are many places with connectivity issues, especially at the village level. This is a major challenge for ordinary free educational activities. It can be said that children from the middle class and urban families have benefited more from the online education system as compared to the online education of rural children.

It can also be said that the educational benefits that can be gained through this are not exhaustive. The sudden infiltration of teachers and students into online education is considered a burdensome activity. Also, it is a new kind of experiential burden for students and teachers for their normal teaching and learning activities. This has created stress at all levels and sometimes psychological problems within educational communities. It is also possible to observe the persistence of these experiences within the primary, intermediate and tertiary education systems. It is the fear of the arrival of a new educational culture in which students do not see the face of teachers and teachers do not face the face of students. Interactions with each other are not much. No face-toface contacts. This weakens the relationship between teachers and students.

\section{ECONOMIC REGRESSION}

The developed countries have tried to mitigate the coronavirus issues and hope to maintain the people's economic complications by their prevailing social welfare system, which was already in practice in the developed world. But unfortunately, that does not apply to the developing countries as these countries were already in the fiscal issues and not an equal social welfare system as followed in the developed countries. Per capita income is lesser than the percentage in the world average in 2019, It was 4011.70 US dollars in 2019 which is equivalent to 32 percent of the world's average (Trading Economics). It indicates that the status of the economy of Sri Lanka.

It creates a huge economic problem for the poorest of the poor, they are the group of people more affected than the other people by this COVID-19 as they are the day-to-day basis breadwinners in the family. The closedown of cities and the lockdown of the areas are created a massive trade and industryrelated crisis in the first wave of COVID-19.

The Tourism industry has seen serious setbacks in the country. According to statistics compiled by the Sri Lanka Tourism Development Authority (SLTDA), foreign exchange earnings from tourism was \$ 3.6 billion in 2019 whereas the tourism industry accounts for $4.3 \%$ of the GDP (Eranda Roshan Fernando, Tuesday, 24 November 2020 00:15). The airports and airline companies closed all over the world, and it consequently, caused the collapse of the international airline transportation network worldwide. Like other countries, it has affected the Sri 
Lankan Economy. The number of arriving tourists has dropped in Sri Lanka and as a consequence, the income of the tourism industry has also declined last year.

Due to the COVID-19 pandemic, in the export sector like agriculture and industry income has decreased in the last year. Exportation income has suddenly declined in Sri Lanka. The foreign exchange income reached adverse conditions. Sri Lankan rupees value against the American dollar's has decreased and by which, the demand of the dollars has increased in Sri Lanka. And therefore, the government of Sri Lanka decided to prohibit many sophisticated importation items including vehicles temporarily.

The slogan of the policy is called "enhancement of domestic economic production", the Government of Sri Lanka has prohibited importing some grocery items. By this, the prices of the local cereals have been increased. Significantly, the government has banned many spices especially turmeric and cereals, to import from foreign countries. It has created an environment to develop a black market and smuggling. There has always been a message on media as a piece of news to the public that there are many smugglings occurred and smugglers that have been arrested, and they are in prison as well.

Many unskilled workers were detained from coming to Sri Lanka from the Middle East. This made that them could not return home country immediately and reunite with their family. Moreover, many in the Middle East suffered from unemployment, homelessness, and food shortages. These affected them not only physically but also mentally. However, it took a long time for the Sri Lankan government to bring them back to Sri Lanka slowly following the health guidelines.

Many entrepreneurs or employers face huge income losses as they are unable to pay salaries and allowances to their employees. Some of them offered a certain percentage reduction in the salaries of the employees for a short period. Daily wage workers also lost their jobs and faced great difficulties in obtaining the money needed for their daily livelihood. The government provided Rs. 5,000 for their livelihood. At the same time, voluntary organizations and well-wishers made donations for their immediate relief.

Livelihood and vulnerability are major problems to society when the coronavirus was beginning. In the Si Lankan context, the population compositions are 18.2 Urban, 77.4 Rural and 4.4 from Estate which is indicated in the August 2018 Central Bank report (Sri Lanka Socio-Economic Data 2018 - Volume XLI, August 2018) from this data, most of the populations are dependent, alive with rural livelihoods, which is their main source of income of the people who are living in rural settings in Sri Lanka. It is mostly relying on agriculture-based livelihood activities, it includes farming, fishing, raring, and so on. By these corona issues, there were many obstacles to their normal livelihood activities, and the income from these agriculture-centered activities has deteriorated. For this reason, most of the rural populations have been badly affected by the loss of assets. The financial assets have declined the value and therefore, the agriculture-related livelihood activities have decreased. Consequently, the usage of natural and physical resources is also weakening. The human capital is also not using appropriately and therefore many people including the poorest of the poor have faced various livelihood and economic related difficulties due to COVID-19 issues. For instance, the fisherfolk have met many issues, farmers, laborers, poor families, women, and children are also facing many difficulties to fulfill even their necessities, for their survival these days. Many people have lost their earning by not doing their livelihood, economic-related activities in Sri Lanka. Therefore, many poor people are facing great challenges to feed their children. According to the Institute of Policy Studies of Sri Lanka (IPS)

"To make matters worse, breadwinners in many poor households have already lost their jobs or sources of income, due to the economic disruption caused by the COVID- 19 crisis. As such, missing out on school meals may lead to nutritional deficits for thousands of poor children in Sri Lanka. This is a grave situation, as nutritional shocks during childhood can result in longterm effects on health and education outcomes" (Jayawardena Priyanka, Jun 09, 2020).

Therefore, Economic and social programs such as small loan schemes that the government has introduced aimed at restructuring the local economy affected by the Covid-19 pandemic. This conveniently reduced the interest rate on loans. As well as lowering interest rates on savings and trying to turn them towards investments.

\section{CUltural FREEZE}

Many novel issues have been rising in the contemporary world in the wake of the Corona Virus. The micro-level individuals, nuclear families, peers, small communities, etc. have been affected in all aspects: physically and mentally/ psychologically owing to this pandemic situation. It has created feelings of sadness in the normal day-to-day life of people worldwide, and it has also affected human behaviour, actions, and so on. The collapse of macro-level societies, institutions, organizations, governments, states, regional countries, could be observed and disorder of normal routines in socio, economic, political, and environmental aspects in the larger settings could also be observed.

For physical and mental wellbeing, sleeping, relaxing, and exercising are very important (Rosemary K.M. Sword and Philip Zimbardo, Mar 17, 2020). Not only these activities, but the healthier nutritious food is also vital for better health management which is a crucial entity to safeguard the human body from Corona Virus. Many health workers including health scientists have been proposing the anti-virus mechanism should be developed through the immune system of the human body that is the best way to overcome coronavirus. To improve the human body's immune system, a daily diet is very important. The diet should have maintained the basic levels of calories with all the nutrition for a healthy life.

So many cultural functions and ceremonies have been disturbed by these coronavirus issues among different cultural groups of people living in a multi-cultural context in Sri Lanka, where different and multi-ethnic, religious, linguistic, and cultural groups have been practicing their cultural practices. Those 
traditional practices have been facing many challenges from the inception of the COVID -19 issues, and the normal cultural life of the people of this island has also become questionable. Several laws and rules have been imposed by the government and the ruling officials like police personals, the army, and other defense people. The health people have also been involved in this safeguarding process. The front-line supporters sacrifice themselves for the social concern and fighting to COVID 19 pandemic for the people's lives in the society.

Normal gathering of the people in day-to-day life activities has also been disturbed, even very close relatives, kin and kith, friends are not gathering and not sharing, not talking to each other face to face as they all be afraid of the seriousness of this problems. People are not ready to move freely because of coronavirus issues.

The psychiatrists counseled people on how to survive the period of the coronavirus outbreak. The psychiatric department focused on maintaining social space, washing hands frequently, and getting used to using disinfectant fluids for this purpose. They provided psychological counseling to people who had been paralyzed in their homes due to the island-wide curfew and how to re-integrate them into social life.

\section{i. Marriage Ceremony}

Marriage is one of the crucial universal social institutions, and this is very much linked with family and appears to be an essential social function for the communities, or the society existence seems to be questionable to a certain extent and related religious, cultural, traditional believes as approved social arrangements, celebrations are also facing several challenges in practice in this pandemic situation. On $30^{\text {th }}$ November 2020, the World Health Organization Director-General's opening remarks at the media briefing on COVID- 19, mentioned that "The COVID- 19 pandemics will change the way we celebrate, but it doesn't mean we can't celebrate. We still can celebrate" (World Health Organization,30 November 2020).

Agreeing with Malinowski's idea that marriage is a contract for the production and maintenance of Children, and Horton and Hunt say that Marriage is the approved social pattern whereby two or more persons establish a family (Sociology Guide, 2020). For instance, the government informed the public that the enforced rule must be maintained when involved in cultural ceremonies. Limitations of cultural activities, restrictions of participants, rules for gatherings, sharing, practical issues related to belief and thus ceremonies have been stopped or reduced, and sometimes people faced many challenges like quarantine has also been witnessed in this island. As a consequence, there have many weddings been stopped or postponed. It creates a new social issue apart from this COVID 19. Individuals, families have been affected by these issues, and the previously prepared arrangements, spending are problematic. According to the Tamils Hindu culture beliefs on marriage, there are some cultural practices to follow, those are very important and therefore, people follow their beliefs and culturally continue, as it has to be maintained by the community as a usual practice. For illustration, the selection of an auspicious time and day for the marriage ceremony is the main aspect when a traditional and cultural way of marriage is taking place. The preparation of "Thaali" (Thaali symbolizes the meaning of Hindu marriage. It is not just an ordinary ornament, but a sign that a Hindu woman is married. It is a symbol of respect, love, and affection. It is worn by the husband to the wife on the wedding day) and the "wedding Rings" for the couples are also crucial, "Taking Saree and Dresses" for bright and the groom and other related activities are also very meaningful in a cultural way of wedding. However, those are not maintained or partly maintained owing to pandemic reasons. For these reasons, there are not only many expenditures in a social, cultural, and economic point of view but also it creates a psychological glitch in individuals and family-wise. it is observed by the researcher one of the e-news called "Batti News", on November $22^{\text {nd, }} 2020$, for misleading the health regulations and instructions, in a wedding ceremony which was held in Northern Part of Sri Lanka, that exceeded the allowed number of participants which were only 50 by the health division, and for not maintaining and following the rules, regulations suggested by the health division, and they have had taken action to quarantine the people who participated the wedding ceremony, including the wedding family and also all the guests in that gathering (Battinews, Sunday, November 22, 2020).

\section{ii. Cremations Issues}

Funerals have also had many challenges, in terms of the traditional, cultural, and religious way which are practiced by the people of Sri Lanka. The government of Sri Lanka has proposed ideas to overcome and reduce the spreading issues related to the coronavirus. Dead bodies of corona people are not allowed to be buried. But, according to the Muslim cultural beliefs, they must bury their dead bodies soon after they die. Therefore, the contradiction comes that the government enforcing some rules and regulations based on health issues, at the same time it denies some of the cultural believes of a community, and it creates a misconception among different communities who are living in this multi-cultural context. On one side of the government reactions to COVID 19, it is facing many challenges to reduce or eradicate the coronavirus issues and for which they introduce new rules and regulations to the people to follow, but on the other side of the reflections by the people towards the government has led to misunderstanding between people of affected communities and the ruling government, as it has elaborated since it has a majority and minorities issues in this Sri Lankan perspective. In addition to that people have fought against government decisions and some are won by the legal way and interpreted in different views.

\section{iii. Social Distancing}

The new conception has ascended in the society after this coronavirus pandemic situation that is "Social Distance" which is interpreted in different forms of explanations. In sociology, social distance means the distance between different groups in society, such as social class, race/ethnicity, gender, or sexuality. In practical use of way, this concept is to some extent be at variance from sociological meaning, which is used for individual distance rather than group distance. To maintain health conditions and to protect humans from the spread of coronavirus, this so-called social distance concept is continued by people everywhere in the contemporary world. 
Originally, the concept of "social distance" began in the mind of George Simmel as a complex interpretation of sociality as forms of "distance" in both a geometric (i.e., Euclidian) and a metaphoric sense. And then, Robert Park's and Emory Bogardus's reformulation of Simmelian social distance and argues that another reformulation of "social distance" is necessary: one which retains both halves of the concept Simmel originally invented. Most of the items in the Bogardus Social Distance Scale are a matter of geometric distance, whereas the significance of geometric distance was completely ignored by Park and Bogardus, in favor of a metaphoric sense of distance (Philip J. Ethington, 1997).

The basics of social distance idea, and then the reformulation of that concept, and the idea changes its meanings in different interpretations with the period. Coronavirus spread is the reason for this change of social distance conceptual meaning. Changes in the concept or new explanations take place as the same in previous times, the reformulation of social distance meaning is interpreted that is for safeguard people from this coronavirus spreads. It controls the Individual-individual, Individual-Group, and Group-Group interactions and gatherings, and people have also been promoted to maintain social distancing, protect and preserve the hygienic environment, and encourage them to avoid crowded places. For which, many Governments impose severe lockdowns around the world and the Sri Lankan government is also carried out quarantined, curfews, and lockdowns (Towards a new Normal, 2020). The belief is that the spreads of coronavirus could be restricted through this social distance monitoring mechanism. The real fact is that practically it is very challengeable, but true according to the health people, scientists, and medical researchers and therefore it is very essential.

On the other side of the social perception of social distancing, lockdown the communities and work from home creates a chance to spend times and sharing loves with their family members and increases of inseparability may lead to the increase of childbirth, and consequently, small social groups like 'family' members are to be closer and the outside leisure activities also have been reduced, and therefore the interactions within the family are very great and the intimacy is also maybe a reason for the increase of the reproduction, which is assumed and could be researchable.

\section{iv. Mindset}

People are in line with the mindset like "to go with the flow", as it is unavoidable pandemic circumstances, where, people accept it, whether like it or not, the world is running today. Anybody cannot simply avoid the extending epidemic issues, which is spreading by various means and ways, where people have to be vigilant, maintain the health immune by healthier foods, carry out good hygienic practices, maintain individual/ social distancing, avoiding gatherings, etc. to eradicate these corona issues.

It is important to note that the front-line health workers, doctors, nurses, and so on, security forces to mitigate the spreading coronavirus, safeguard people through their health services, maintain the rules and regulations have been imposed by the government, they are the people in unavoidable threat risk by this situation, as they are trained health professional and health workers are facing severe mental and physical health problems to work for others. But for survival people must do the needful, which depends on their socio-economic conditions, and the people must move freely for their necessities. The socio-economic importance is a crucial aspect for the survival of the people. According to Darwinism, "survival of the fittest" from sociologist Herbert Spencer and "struggle for existence" from economist Thomas Malthus, concepts are identical and meaningful, "all species of organisms arise and develop through the natural selection of small, inherited variations that increase the individual's ability to compete, survive and reproduce" (Gough, Ian, Runciman, Garry, Mace, Ruth, Hodgson, Geoffrey and Rustin, Michael,2008) and the researchers found that those above mentioned conceptual theories are applicable, for the human safety and survival, from coronaviruses in this contemporary pandemic world today as well.

It is witnessed that people are mentally sick due to this COVID -19 issues worldwide, and many cases with mental illness have also been reported after the arrival of coronavirus. The people have a feeling that they are deprived of their normalcy and which leads to various social disorders like jobless, no schooling, no entertainment, and reduced sports activities, starvation, economic crisis, forced quarantines, stress, depression, and including an increase of suicides. Thus, there are several suicidal attempts have also happened and some of them have lost their lives by committing suicide, because of the corona fear and pressure. Referring to news items in the Battinews.com on December 06. 2020 "a young family woman, 35 years old committed suicide by setting fire herself as the anxiety of corona in Vellavely, Batticaloa, Sri Lanka. She is a mother of two children, and this family had visited their relatives' house, which is in another district named Anuradhapura, and consequently, they were quarantined by Public Health Inspectors (PHI) and therefore, she got depressed by this corona fear, which leads to her disorder mind and committed suicide herself (Battinews, Sunday, December 06, 2020). It is noted that the prevailing social pathetic condition is a reason for mental illnesses, and it leads to suicidal attempts. "Social isolation, anxiety, fear of contagion, uncertainty, chronic stress and economic difficulties may lead to the development or exacerbation of depressive, anxiety, substance use and other psychiatric disorders and people who reside in high COVID-19 prevalence areas" (Sher Leo, 30 June 2020).

Therefore, people are in need to fulfil sociological, anthropological, psychological, economical, and essential satisfactions to safeguard people from social psychological issues, and which would contribute to curtailing the suicidal attempts and losses from suicide. According to Washington, DC, September 10, 2020, Pan American Health Organization (PAHO) mentioned that "We still don't know how increased depression, domestic violence or substance use will impact suicide rates in the region, but it's important to take a minute to talk about it, support each other in these pandemic times, and know the warning signs of suicide to help prevent it" (Pan American Health Organization and World Health Organization10 Sep 2020). 


\section{CONCLUSIONS}

At the micro-level, there are various socio-economic impacts. Daily workers, especially western Province workers, have lost their main income. Also, people faced difficulties in accessing essential goods and other services due to the mobile restrictions imposed on them. In this context, the government faced the challenge of implementing new strategies to provide support to maintain the daily lives of the people while better managing the task of preventing the spread of the virus in the community. The government should continue to review the Social Security program, develop a long-term strategy for Social Security, and provide immediate assistance to those in need.

It is the responsibility of the government to protect the poor and vulnerable. The economic burden borne by COVID-19 cannot be borne equally by all. Therefore, it is very important to protect the poor and vulnerable. The government must make timely interventions related to welfare needs and constantly monitor the impact of a possible crisis in the labor market.

The spread of COVID-19 pandemic disease created a health crisis and a continuing socio-economic crisis in Sri Lanka. This has had very adverse socio-economic consequences. Lockdown began to directly affect Sri Lanka's manufacturing economy. More than this, the Sri Lankan tourism sector has suffered a very adverse setback. The tourism sector contributes approximately $5 \%$ to Sri Lanka's foreign exchange earnings. International transport was banned as airports and airlines closed. Revenue from tourist arrivals has reached zero.

International demand for exported goods may decline in some sectors. This can affect the pay for them. Production for these products, however, is largely unrestricted. Eighty percent of Sri Lanka's agricultural land is cultivated by small farmers. To increase their income, they need to diversify into more commercially viable crops. Help to adapt to new technologies, improve marketing, and adapt to climate change. The government should work with the private sector to create the necessary infrastructure and the foundation to bring in the necessary funding and resources. Accordingly, it is the responsibility and duty of the government to change the policies and attitudes of the public sector. Industrial and agricultural exports fell sharply. As a result, Sri Lanka's export earnings fell sharply. The government faced great difficulties in obtaining the US dollar for foreign exchange. The government has suspended imports of luxury goods, especially motor vehicles. The government stopped imports of certain items to be under the policy of increasing local agricultural production.

Human capital is the real wealth and best resource of a nation. Preschools, Schools, and Universities were closed during the epidemic. The online learning system, including television and radio, and e-learning, supported schools and university students. For decades, the government has supported the development of free health care and education with the support of the World Bank.

In such a special situation, better administrative and political coordination is very important for the country. Government leadership is important among the medical sector, law enforcement, civil service, and other relevant stakeholders to meet the challenges posed by COVID-19. The government did it very well in the first wave of the COVID-19 outbreak. Sri Lankans do not have the awareness to prevent the second wave of COVID19 outbreaks. Sri Lankans have been facing the second wave of irresponsible social activities.

Finally, the effects of COVID -19 complications should be examined in depth. People need to accept this serious virus problem and its consequences. And take the necessary steps to reduce or eliminate this virus from the world. This requires a special approach to global health promotion. This may be a longterm basic approach. Therefore, the human body needs to increase its immunity to protect itself from the coronavirus and its effects.

\section{REFERENCES}

[1] Battinews, Sunday, November 22, 2020, URL Available, http://www.battinews.com/2020/11/blog-post_771.html

[2] Battinews, Sunday, December 06, 2020, URL Available on http://www.battinews.com/2020/12/corona-anxiety\%20.html

[3] Colombo Page News Desk, Sri Lanka, Sri Lanka Supreme Court Allows Dissolution of parliament and June 20 election Tue, Jun 2, 2020, 08:58 pm SL Time, URL Available on http://www.colombopage.com/archive_20A/Jun02_1591111706CH.php

[4] Eranda Roshan Fernando, Daily FT, Tuesday, 24 November 2020 00:15), COVID-19 and the recovery of the tourism industry, COVID-19 and the recovery of the tourism industry | Daily FT

[5] Garda World, 20 Mar 2020, 11:49 AM UTC) Sri Lanka: Nationwide curfew implemented March 20-23 /update 5, https://www.garda.com/crisis24/newsalerts/324931/sri-lanka-nationwide-curfew-implemented-march-20-23update-5

[6] Garda World,19 Mar 2021, 05:12 AM UTC, Sri Lanka: Government relaxing quarantine measures for some travelers as of March 19 /update 43, https://www.garda.com/crisis24/news-alerts/457416/sri-lanka-governmentrelaxing-quarantine-measures-for-some-travelers-as-of-march-19-update43\#: :text=Sri\%20Lankan\%20residents \%2C\%20as\%20well,days\%20at $\% 2$ $0 \mathrm{a} \% 20$ special\%20facility.

[7] Garda World,20 Mar 2020|11:49 AM UTC, Sri Lanka: Nationwide curfew implemented March 20-23 /update 5, https://www.garda.com/crisis24/newsalerts/324931/sri-lanka-nationwide-curfew-implemented-march-20-23update-5

[8] Gough, Ian, Runciman, Garry, Mace, Ruth, Hodgson, Geoffrey and Rustin, Michael,2008, Darwinian evolutionary theory and the social sciences, Twenty-first-century society, 3 (1), Taylor \& Francis Group URL Available on

https://eprints.lse.ac.uk/36719/1/Darwinian\%20evolutionary\%20theory(lser o).pdf

[9] Jayawardena Priyanka, Jun 09, 2020, No School, No Meals: Sri Lanka's Battle against Child Malnutrition amidst COVID-19, Talking Economics, URL Available on https://www.ips.lk/talkingeconomics/2020/06/09/noschool-no-meals-sri-lankas-battle-against-child-malnutrition-amidst-covid$19 /$

[10] Krishnamohan.T,2020, The Ethno-political Polarization Scenario in Sri Lanka's Presidential Election held in November 2019: A Critical View, International Journal of Research and Innovation in Social Science (IJRISS) vol.4 issue 1, pp.140-146 January 2020 URL Available on https://www.rsisinternational.org/journals/ijriss/Digital-Library/volume-4issue-1/140-146.pdf

[11] Krishnamohan.T, \& Sathiyasegar.K,2020, The Ninth Parliamentary Election of Sri Lanka in 2020: An Analysis of the Outcomes, International Journal of Scientific and Research Publications, Volume 10, Issue 10, October 2020, URL Available on http://www.ijsrp.org/research-paper-1020/ijsrpp10659.pdf

[12] News 1st,16 Mar 2020, 3:43 PM, GMOA \& BASL request the government to extend holidays, News 1st, MTV Channel (Pvt) Ltd, MBC Networks (Pvt) Ltd, 45/3, Braybrooke Street, Colombo-02, 
https://www.newsfirst.lk/2020/03/16/gmoa-basl-request-the-government-toextend-holidays/

[13] Philip J. Ethington, 1997, The intellectual Construction of "Social Distance": Toward a Recovery of George Simmel's Social Geometry, Cybergeo: European Journal of Geography, Epistemology, History, Teaching, URL Available on https://journals.openedition.org/cybergeo/227?lang=en

[14] Rosemary K.M. Sword and Philip Zimbardo, Mar 17, 2020,4 Coping Skills for This Trying Time Easy tips to help keep sane during the coronavirus pandemic, URL Available https://www.psychologytoday.com/us/blog/the-time-cure/202003/4-copingskills-trying-time

[15] Sher Leo, 2020, The impact of the COVID-19 pandemic on suicide rates, Review, QJM: An International Journal of Medicine, 2020, Vol. 113, No. 10 Oxford University Press on behalf of the Association of Physicians, URL Available on https://academic.oup.com/qjmed/article/113/10/707/5857612

[16] Sociology Guide, 2020, URL Available on https://www.sociologyguide.com/marriage-family-kinship/Marriage.php.

[17] Trading Economics, URL Available on https://tradingeconomics.com/srilanka/gdp-per-capita

[18] Sri Lanka Socio-Economic Data 2018 - Volume XLI, August 2018, Statistics Department, Central Bank of Sri Lanka Colombo, Sri Lanka, URL Available on

https://www.cbsl.gov.lk/sites/default/files/cbslweb_documents/statistics/Sri _Lanka_\%20Socio_Economic_Data_2018_e.pdf

[19] The Constitution of Democratic Socialist Republic of Sri Lanka (As Amended Up To 29th October 2020) Revised Edition - 2021, file:///F:/Constitution/constitution-2021.pdf

[20] Towards a New Normal, 2020, Advocacy Brief: Resumption of Public Activities During Gradual Exit from Existing Restrictions for Covid-19 in Sri Lanka, Ministry of Health and Indigenous Medical Services, World Health
Organization, Government Medical Officers Association and Sri Jayewardenepura Kotte Municipal Council, URL Available on https://medicine.kln.ac.lk/images/2020/advocacy-brief_.pdf

[21] The New Indian Express, 14th June 2020 04:51 PM, The Election Commission of Sri Lanka conducted a series of mock polls to test the health guidelines for the election, URL Available on https://www.newindianexpress.com/world/2020/jun/14/sri-lankas-electioncommission-expresses-satisfaction-over-poll-preparations-2156510.html

[22] The Gazette of The Democratic Socialist Republic of Sri Lanka, Extraordinary, No. 2165/8 - Monday, March 02, 2020, URL Available on http://www.documents.gov.lk/files/egz/2020/3/2165-08_E.pdf

[23] WHO Director-General's opening remarks at the media briefing on COVID19,30 November 2020, URL Available on https://www.who.int/directorgeneral/speeches/detail/who-director-general-s-opening-remarks-at-themedia-briefing-on-covid-19---30-november-2020

\section{AUTHORS}

First Author - Professor Thanabalasingam Krishnamohan, Professor in Political Science, Department of Social Sciences, Eastern University, Sri Lanka, Chenkalady, Sri Lanka, tkmatura29@gmail.com

Second Author - Mr.Kandasamy Sathiyasegar, Senior Lecturer in Sociology \& Anthropology, Department of Social Sciences, Eastern University, Sri Lanka, Chenkalady, Sri Lanka, sathiyasegar@gmail.com 